Original Research Article

\title{
Introduction of web based e-learning in pharmacology: an innovative way
}

\author{
Manish Barvaliya, Ashish Anovadiya*, Bhargav M. Purohit
}

\begin{abstract}
Department of Pharmacology, Government Medical College, Bhavnagar, Gujarat, India
\end{abstract}

Received: 08 August 2018

Accepted: 31 August 2018

*Correspondence to:

Dr. Ashish Anovadiya, Email: ashishanovadiya@ yahoo.com

Copyright: (C) the author(s), publisher and licensee Medip Academy. This is an openaccess article distributed under the terms of the Creative Commons Attribution NonCommercial License, which permits unrestricted noncommercial use, distribution, and reproduction in any medium, provided the original work is properly cited.

\begin{abstract}
Background: In current scenario, poor attendances in classes and poor performances of students are a stimulus to think beyond the conventional teaching approach. Being current digital generation, students may show their affection to e-learning. Aim of this study was to introduce the e-learning in Pharmacology with objectives to evaluate its acceptability by students and faculties and learning gain of students
\end{abstract}

Methods: Four inter-related e- modules for a topic "drugs used in treatment of bronchial asthma" were prepared and provided to the students. Pre-test was conducted before giving E-modules. Students were instructed to complete the emodules in seven days and post-test was conducted on last day. Feedbacks from students and faculties were collected. Learning gain of students was evaluated along with their acceptability for e-modules.

Results: Total of 147 students participated in the study but, 130 students completed pre-test and post-test, both. The absolute learning gain (\% post-test score - $\%$ pre-test score) was found $23.3 \pm 19.2 \%$. The class average normalized learning gain was found $0.32(32 \%)$ that was significant, as per Hake's criteria for the effectiveness of educational interventions. Slow speed of internet, background noise in modules, and size of e-modules were some technical problem faced by students. The most of students perceived the modules positively and demanded the e-modules for other topics. The faculties also perceived it positively and suggested to use e-modules additionally to classroom lectures. Conclusions: E-learning modules were taken positively by students and faculties and resulted in significant learning gain.

Keywords: E-learning, E-modules, Medical education, Teaching-learning

\section{INTRODUCTION}

E-learning refers to a collection of learning methods using digital technology which enable, distribute and enhance learning. ${ }^{1}$ It can enhance knowledge, performance and responsiveness of the learners by providing learner supportive environment. Traditional teaching-learning methods are teacher oriented and not learner supportive. In current scenario, poor attendances in classes and poor performances of students are a stimulus to think beyond the conventional teaching approach. Learners of current generation may have more acceptability towards elearning as they are more familiar to information and communication technology. ${ }^{1} \quad$ A competency-based curriculum is based on learning outcome and it shifts medical education from teacher-oriented to more student- centred. ${ }^{2}$ The demand of e-learning has increased due to its flexibility, access to reach a wider audience and the potential for cost reduction in the long-term. Some published studies have shown improved level of learning and its acceptability to the students with e-learning. ${ }^{3-5}$ The use of e-learning is limited in medical education in India. The present study is aimed to introduce web based elearning in pharmacology and to evaluate its acceptability (Kirkpatrick level 1) and effectiveness (Kirkpatrick level 2) among second year medical students. ${ }^{6}$

\section{METHODS}

Ethics committee permission was taken from Institutional Review Board, Government Medical College, Bhavnagar and written informed consent was obtained from all the 
participating students. This was a single group prospective educational study conducted on second year medical students between October 2017 and December 2017 at Department of Pharmacology, Government Medical College, Bhavnagar.

\section{Preparation of e-learning modules}

The project was discussed with other faculties of the department. "Drugs used in treatment of bronchial asthma" was chosen to be covered by e-learning as it is from core area of Pharmacology. The specific learning objectives were framed and discussed. ${ }^{4}$ short interrelated interactive presentations were prepared for e-learning with the help of other faculties of department. Topics covered under each module were as following.

\section{Table 1: Topics covered under each module.}

\begin{tabular}{|c|c|}
\hline Module & Topic \\
\hline E-module 1 & $\begin{array}{l}\text { Introduction of bronchial asthma } \\
\text { (Patho-physiology and drug } \\
\text { classification) }\end{array}$ \\
\hline E-module 2 & $\begin{array}{l}\text { Bronchodilator drugs (Reliever } \\
\text { medications) }\end{array}$ \\
\hline E-module 3 & $\begin{array}{l}\text { Anti-inflammatory drugs (Controller } \\
\text { medicines) }\end{array}$ \\
\hline E-module 4 & Management of Bronchial asthma \\
\hline Videos & $\begin{array}{l}\text { How to use metered dose inhaler, dry } \\
\text { powder inhaler and nebulizer }\end{array}$ \\
\hline
\end{tabular}

iSpring Suite 8 (Demo version) software was used to record the narrations and create video of recorded presentations. Pre-defined specific learning objectives were included in beginning of E-learning module. All prepared E-modules were uploaded in google drive.

Authors have created the website (https://drmanishbarvaliya.wixsite.com/pharmacology) using wix.com and all the videos were linked with the website.

\section{Preparation of pre-test and post-test; Feedback form}

Pre-test and post-test included 15 multiple choice questions, one True/false type and 2 open ended questions with total score of 20 . Feedback form was designed for rating of e-modules, perceptions for e-module/learning on 5 point likert scale and open ended questions to receive free comments. All these documents were given to other faculties for scrutiny and necessary modifications were done after discussion to finalize them.

There were total 4 contact sessions in the study. These contact sessions were carried out during lecture hours. In first contact session, students were informed about study objectives, procedures and assessment methods. Pre-test assessment was carried out at the same time. All the emodules were provided sequence wise every alternate day to the students and instructed to go through E-learning modules within 7 days. Authors have used whatsapp group of study participants to deliver learning resource materials, to remind study timelines and schedule of the assessment. Students were followed up in 2 contact sessions conducted on 3rd and 5th day of study procedure. Their difficulties were discussed during contact sessions and using whatsapp group. On last day in $4^{\text {th }}$ contact session, Posttest assessment was performed, and feedback was collected from the students. Students had to self-report the number of e-modules they have gone through while giving feedback. Faculties and resident doctors of pharmacology were made aware regarding e-learning. All resource material was delivered to them through whatsapp and email. Their feedback was also collected.

\section{Data analysis}

Assessment of pre-test and post-test was done by a same assessor. Checklist for assessment of open ended questions was given to the assessor and assessor did not know that whether he was assessing pre-test or post-test. All collected data were entered in Microsoft excel for calculation. A difference in pre-test and post-test score was analysed by Wilcoxon Matched Pairs test. Authors have calculated the absolute learning gain (\% post-test score $\%$ pre-test score).

Authors have evaluated the effectiveness of the intervention by using class average normalized gain $(\mathrm{g}=$ (\% post-test score - \% pre-test score)/ (100 - \% pre-test score). The class average normalized gain of $0.3(30 \%)$ was considered significant, as per Hake's criteria for the effectiveness of educational interventions. ${ }^{7}$

Descriptive statistics was used for closed ended feedback data. Free comments of students and faculties were analysed by looking into the common pattern and drawing conclusions. Graphpad Instat3 demo version was used for statistical calculations and $\mathrm{P}$ value $<0.05$ was considered as statistically significant.

\section{RESULTS}

Total 147 students participated in the study. However, 130 students gave pre-test and post-test both and feedback was given by all 147 students. Total 12 faculties from Pharmacology provided their feedback.

The students used their personal internet facilities to access the videos. Average time spent on e-modules by students for learning was $4.5 \pm 2.7 \mathrm{hrs} .80(54.4 \%)$ out of 147 students went through all 4 e-modules + videos; 39 (26.5\%), $26(17.7 \%)$ and $02(1.4 \%)$ students went through 4, 3 and 1 e-modules, respectively. Rating for e-modules by students and faculties is shown in Table 2 and 3, respectively. Perceptions of students and faculties for conducted E-learning activity are presented in Table 4 and 5 , respectively. 
Difference between pre-test score and post-test score was found statistically significant (Table 6).
The absolute learning gain was found $23.3 \pm 19.2 \%$ (Table $6)$.

Table 2: Student's rating for e-modules.

\begin{tabular}{|lllllll|}
\hline Rating for & Very good & Good & Acceptable & Poor & Very poor & Not responded \\
\hline Clarity of multimedia & $71(48.3)$ & $66(44.9)$ & $09(6.1)$ & 00 & 00 & $01(0.7)$ \\
\hline Audibility & $53(36.1)$ & $70(47.6)$ & $20(13.6)$ & $02(1.4)$ & $01(0.7)$ & $01(0.7)$ \\
\hline Narrations & $61(41.5)$ & $73(49.7)$ & $10(6.8)$ & $01(0.7)$ & 00 & $02(1.4)$ \\
\hline Over all & $70(47.6)$ & $68(46.3)$ & $07(4.8)$ & 00 & 00 & $02(1.4)$ \\
\hline
\end{tabular}

Values in () are in percentage

Table 3: Faculty's rating for e-modules.

\begin{tabular}{|llllll|}
\hline Rating for & Very good & Good & Acceptable & Poor & Very poor \\
\hline Clarity of multimedia & $07(58.3)$ & $04(33.3)$ & $01(8.3)$ & 00 & 00 \\
\hline Audibility & $06(50)$ & $05(41.7)$ & $01(8.3)$ & 00 & 00 \\
\hline Narrations & $07(58.3)$ & $04(33.3)$ & $01(8.3)$ & 00 & 00 \\
\hline Over all & $06(50)$ & $04(33.3)$ & $02(16.7)$ & 00 & 00 \\
\hline
\end{tabular}

Values in () are in percentage

Table 4: Student's perception for e-learning activity.

\begin{tabular}{|c|c|c|c|c|c|c|}
\hline Statements & $\begin{array}{l}\text { Strongly } \\
\text { agree }\end{array}$ & Agree & $\begin{array}{l}\text { Can't } \\
\text { say }\end{array}$ & Disagree & $\begin{array}{l}\text { Strongly } \\
\text { disagree }\end{array}$ & $\begin{array}{l}\text { Not } \\
\text { responded }\end{array}$ \\
\hline E-modules were user friendly & $64(43.5)$ & $79(53.7)$ & $03(2.1)$ & 00 & 00 & $01(0.7)$ \\
\hline $\begin{array}{l}\text { Content was informative and logically } \\
\text { structured }\end{array}$ & $55(37.4)$ & $84(57.1)$ & $04(2.7)$ & $02(1.4)$ & 00 & $02(1.4)$ \\
\hline $\begin{array}{l}\text { Time duration of each E-module was } \\
\text { appropriate }\end{array}$ & $69(46.9)$ & $71(48.3)$ & $05(3.4)$ & $02(1.4)$ & 00 & 00 \\
\hline Pace of learning was proper & $54(36.7)$ & $80(54.4)$ & $11(7.5)$ & $01(0.7)$ & 00 & $01(0.7)$ \\
\hline E modules were interesting & $70(47.6)$ & $63(42.9)$ & $09(6.1)$ & $02(1.4)$ & $01(0.7)$ & 00 \\
\hline Increased understanding for subject matter & $85(57.8)$ & $52(35.4)$ & $09(6.1)$ & 00 & $01(0.7)$ & 00 \\
\hline $\begin{array}{l}\text { E-modules are important resources for self- } \\
\text { directed learning }\end{array}$ & $89(60.5)$ & $49(33.3)$ & $08(5.4)$ & 00 & 00 & $01(0.7)$ \\
\hline E modules are better than classroom lectures & $84(57.1)$ & $42(28.6)$ & $19(12.9)$ & $01(0.7)$ & $01(0.7)$ & 00 \\
\hline SLOs are achieved & $56(38.1)$ & $84(57.1)$ & $04(2.7)$ & $01(0.7)$ & 00 & $02(1.4)$ \\
\hline $\begin{array}{l}\text { E-learning will enhance your performance in } \\
\text { future exam }\end{array}$ & $70(47.6)$ & $56(38.1)$ & $21(14.3)$ & 00 & 00 & 00 \\
\hline $\begin{array}{l}\text { E- learning modules will make your studies } \\
\text { easier }\end{array}$ & $82(55.8)$ & $54(36.7)$ & $08(5.4)$ & $03(2.1)$ & 00 & 00 \\
\hline
\end{tabular}

Values in () are in percentage

Table 5: Faculty's perception for e-learning activity.

\begin{tabular}{|c|c|c|c|c|c|}
\hline Statements & $\begin{array}{l}\text { Strongly } \\
\text { agree }\end{array}$ & Agree & $\begin{array}{l}\text { Can't } \\
\text { say }\end{array}$ & Disagree & $\begin{array}{l}\text { Strongly } \\
\text { disagree }\end{array}$ \\
\hline E-modules were user friendly & $04(33.3)$ & $07(58.3)$ & $01(8.3)$ & 00 & 00 \\
\hline Content was informative \& logically structured & $09(75)$ & $02(16.7)$ & $01(8.3)$ & 00 & 00 \\
\hline Time duration of each E-module was appropriate & $06(50)$ & $04(33.3)$ & $02(16.7)$ & 00 & 00 \\
\hline Pace of learning was proper & $06(50)$ & $04(33.3)$ & $02(16.7)$ & 00 & 00 \\
\hline E modules were interesting & $04(33.3)$ & $07(58.3)$ & $01(8.3)$ & 00 & 00 \\
\hline E-modules are important resources for self-directed learning & $05(41.7)$ & $06(50)$ & $01(8.3)$ & 00 & 00 \\
\hline E modules are better than classroom lectures & $04(33.3)$ & $01(8.3)$ & $05(41.7)$ & $01(8.3)$ & $01(8.3)$ \\
\hline E- learning modules will make studies easier in future & $03(25)$ & $05(41.7)$ & $03(25)$ & $01(8.3)$ & 00 \\
\hline E modules enhances learning among students & $04(33.3)$ & $06(50)$ & $02(16.7)$ & 00 & 00 \\
\hline
\end{tabular}

Values in () are in percentage 
The class average normalized learning gain was found 0.32 $(32 \%)$ that was significant, as per Hake's criteria for the effectiveness of educational interventions (Table 6). 137 students responded as "No" to the question of need for classroom lecture for the same topic taught by e-modules whereas 7 students asked for classroom lecture for this

Faculties suggested teaching the topic using e-modules in addition to classroom lecture (Table 7). Strength, weakness topic. $83(56.5 \%)$ and $62(42.2 \%)$ students were interested to learn through e-modules only and e-modules in addition to class-room lecture, respectively. 141 students demanded e-modules for other topics in Pharmacology. 9 out 12 faculties were in favor of giving e-modules on regular basis. ${ }^{11}$

of conducted teaching activity and suggestions by students and faculties are presented in Table 7.

Table 6: Learning gain by the students.

\begin{tabular}{|llll|}
\hline Score/Gain (\%) Total score - 20 & Mean (SD) $(\mathbf{n = 1 3 0})$ & 95\% CI & P value \\
\hline Pre-test score (\%) & $29.7(12.0)$ & $27.6-31.8$ & $<0.0001$ \\
\hline Post-test score (\%) & $53(18.3)$ & $49.9-56.2$ & \\
\hline Absolute learning gain (\%) & $23.3(19.2)$ & $20.0-26.6$ & - \\
\hline Class-average normalized gain (\%) & $0.32(0.27)$ & $0.28-0.37$ & - \\
\hline
\end{tabular}

Table 7: Feedback for strength and weakness and suggestions provided by students and faculties of conducted elearning activity.

\begin{tabular}{|c|c|c|}
\hline Strength & Weakness & Suggestions \\
\hline $\begin{array}{l}\text { Simple, systematically explained, easy } \\
\text { to understand and revise }\end{array}$ & Sound quality & $\begin{array}{l}\text { Improve image quality in slide } \\
\text { and add more animation }\end{array}$ \\
\hline Learning at own time, place and pace & $\begin{array}{l}\text { Video size and quality of some images } \\
\text { in slides }\end{array}$ & Add more MCQs \\
\hline Self learning opportunity & Speedy explanation at some slide & Include mnemonic \\
\hline Assignment at the end & $\begin{array}{l}\text { Matching narration with slide content } \\
\text { difficult }\end{array}$ & $\begin{array}{l}\text { Doubt clearing session should be } \\
\text { conducted }\end{array}$ \\
\hline Short duration & No direct interaction with teacher & Provide e-modules for other topics \\
\hline SLOs at beginning & Less content for individual drugs & Make it for NEET- PG \\
\hline Active and independent learning & Too much content for UG & Reduce size and duration of module \\
\hline
\end{tabular}

\section{DISCUSSION}

In present study, Authors have introduced short interrelated four E-learning modules for a topic "drugs used in bronchial asthma" to second year medical students and analysed its effectiveness through one-group pre-test/posttest study design. Authors have also assessed its acceptability to the students and faculty.

Authors have found significantly higher post test score as compared to pre-test score of students [29.7 (12.0) vs. 53 (18.3); $\mathrm{P}<0.0001]$. This finding was similar to the findings of previous studies where significant learning gain occurred. ${ }^{1,3,4,8}$ An absolute learning gain is difference between post-test score and pre-test score. Authors have observed the absolute learning gain of $23.3 \%$ that in trend with the earlier study of e-learning in pharmacy education. ${ }^{9}$ The class average normalized gain does not depend on the study group's pre-test score. The class average normalized gain of $0.3(30 \%)$ is considered significant, as per Hake's criteria for the effectiveness of educational interventions. ${ }^{7}$
In present study, an observed class average normalized gain was $32 \%$. Thus, findings of the present study suggest the significant learning gain by the students.

Authors have observed the positive perception of students to the e-learning modules. Perceived usefulness and ease of use are the key variables that influence students' attitude, intention, and actual behaviour to use a new technology. ${ }^{10,11}$ In present study, the students found the emodules useful for easy learning at their own convenience. However, a teacher being novice in preparing e-modules, some technical problems were there in e-modules those were reflected in students' feedback. The most common technical problem was sound problem. Even though, recording of narrations were done at late night with complete silence, there was some continuous background noise in each module that was irritating to most of the students. Authors have used software to remove that irritating background noise based on the feedback from students. The second common problem was size and video quality of e-modules. While converting narrated power 
point presentation in to video, Authors have found some blurring of fonts and images in converted video. If Authors have kept the size of module less then, this blurring is even more. Another problem was, the pointer was not recorded in the videos that created a problem to students as they were not able to match the narration with content of some slides. The technical issues should be kept in mind while preparing the e- modules. Despite of these technical issues, acceptability of students for e-modules was high as they asked for the e-modules on regular basis. Authors have facilitated e-modules through e-mail, whatsapp and website. Some students who were having internet related issue approached us to get the videos in their pen-drive. emodules were perceived positively by other teaching faculties. They felt them informative, easy to understand and interesting. However, they suggested using e-modules in addition to traditional lecture. Lack of interaction with facilitator has been pointed out as limitation of e-modules. Authors have included some multiple choice questions at the end of each module for self-assessment and students like it the most. $83(56.5 \%)$ and $62(42.2 \%)$ students were interested to learn through e-modules only and e-modules in addition to class-room lecture, respectively. 11 of 12 faculties suggested that e-modules should be used as supplementary to class-room lecture. Some students also mentioned lack of direct interaction with teacher as weakness of e-learning. If authors have use only e-learning as teaching-learning method, students may stop attending the classes. E-modules are good for easy learning at convenient time but, teaching of some skills require direct contact between teacher and student. All these factors should be kept in mind while promoting e-modules as teaching-learning tool. This study was with several limitations. Authors have conducted the teaching-learning activity for a single topic only and findings are based on that only. Based on feedback given by students and faculties, strategies can be made for more topics. Authors have could not assess the long-term learning gains and behavioural change.

\section{CONCLUSION}

Introduction of e-learning modules for "drugs used in bronchial asthma" were taken positively by students and faculties. Both students and faculties suggested that the elearning modules should be provided for other topics. Faculties also suggested that e-learning modules should not be the substitute for traditional lecture. e-modules caused in significant learning gain to the students. Students perceived e-modules as powerful tool for self-directed learning however; they want availability of teachers for doubt clearings.

\section{ACKNOWLEDGEMENTS}

Authors have would like to thank faculties of Advance Course in Medical Education, Pramukhswami Medical
College, Karamsad and Pharmacology faculties of Government Medical College, Bhavnagar for their help in conductance of the study.

Funding: No funding sources

Conflict of interest: None declared

Ethical approval: The study was approved by the Institutional Ethics Committee

\section{REFERENCES}

1. Gaikwad N, Tankhiwale S. Interactive E-learning module in pharmacology: a pilot project at a rural medical college in India. Perspectives Med Edu. 2014 Jan 1;3(1):15-30.

2. Zollner B, Sucha M, Berg C, Muß N, Amann P, Amann-Neher B, et al. Pharmacases. De-A studentcentered e-learning project of clinical pharmacology. Med Teacher. 2013 Mar 1;35(3):251-3.

3. Tse MM, Lo LW. A Web-based e-learning course: integration of pathophysiology into pharmacology. Telemed J E-Health 2008;14(9):919-24.

4. Baumann-Birkbeck L, Karaksha A, AnoopkumarDukie S, Grant G, Davey A, et al. Benefits of elearning in chemotherapy pharmacology education. Curr Pharma Teaching Learning. 2015 Jan 1;7(1):10611.

5. Gutmann J, Kühbeck F, Berberat PO, Fischer MR, Engelhardt S, Sarikas A. Use of learning media by undergraduate medical students in pharmacology: a prospective cohort study. PLoS One. 2015 Apr 7;10(4):e0122624.

6. Kirkpatrick DL. Evaluating Training Program: The Four Level. 2 $2^{\text {nd }}$ Ed. San Francisco, CA: BerrettKoehler Publisher; 1998.

7. Hake RR. Interactive-engagement versus traditional methods: a six-thousand-student survey of mechanics test data for introductory physics courses. Am J Physics. 1998 Jan;66(1):64-74.

8. Silva CS, Souza MB, Silva Filho RS, Medeiros LM, Criado PR. E-learning program for medical students in dermatology. Clinics. 2011;66(4):619-22.

9. Salter SM, Karia A, Sanfilippo FM, Clifford RM. Effectiveness of E-learning in pharmacy education. Am J Pharmaceut Education. 2014 May 15;78(4):83.

10. Ngampornchai A, Adams J. Students' acceptance and readiness for E-learning in Northeastern Thailand. Int J Educational Technol Higher Edu. 2016 Dec;13(1):34.

11. Davis FD, Bagozzi RP, Warshaw PR. User acceptance of computer technology: a comparison of two theoretical models. Management Sci. 1989 Aug;35(8):982-1003.

Cite this article as: Barvaliya $\mathrm{M}$, Anovadiya A, Purohit BM. Introduction of web based e-learning in pharmacology: an innovative way. Int J Basic Clin Pharmacol 2018;7:2016-20. 